\title{
Effect of Different Levels, Sources and Methods of Application of Nitrogen on Growth and Yield of Wheat (Triticum aestivum L.)
}

\author{
Devendra Kumar Inwati*, Janardan Yadav, Jay Shankar Yadav, \\ Giriraj and Astha Pandey
}
Department of Soil Science and Agricultural Chemistry, Institute of Agricultural Sciences, Banaras Hindu University, Varanasi, UP-221005, India

*Corresponding author

\section{A B S T R A C T}

\begin{tabular}{|c|}
\hline Keywords \\
\hline $\begin{array}{l}\text { Wheat, Polymer } \\
\text { Coated Urea (PCU), } \\
\text { Normal urea, Slow } \\
\text { releasing fertilizer }\end{array}$ \\
\hline Article Info \\
\hline $\begin{array}{l}\text { Accepted: } \\
\text { 20 January } 2018 \\
\text { Available Online: } \\
\text { 10 February } 2018\end{array}$ \\
\hline
\end{tabular}

\section{Introduction}

Wheat (Triticum aestivum L.) is the second most important cereal crop in India, after rice, both in term of area and production. It provides about $20 \%$ of food energy and protein worldwide. United States Department of Agriculture (USDA) estimates that the World Wheat Production during 2016-2017 will be 751.36 million metric tons in the area of 221.73 million hectares with an average yield of 3.39 metric tons/hectare. In India wheat production is 87 million metric tons in area of 30.22 million hectare in average of 2.88 metric tons/hectare. Wheat is therefore an important source of both carbohydrates and protein for human and livestock nutrition (Shewry, 2009). Wheat is a Rabi crop. It is sown in mid-October-mid-November and harvested in March. It grows well in cool, moist climate and ripens in a warm, dry climate.

There are problems associated with $\mathrm{N}$ fertiliser use, because $\mathrm{N}$ can leach and cause eutrophication of water (Vitousek et al., 1997), and $\mathrm{N}$ fertilization increases emissions of the greenhouse gas like nitrous oxide $\left(\mathrm{N}_{2} \mathrm{O}\right)$ from agricultural soils (Bouwman et al., 2002). Volatile ammonia emissions from 
fertiliser contribute to deposition of $\mathrm{N}$ in unmanaged ecosystems (Vitousek et al., 1997). However, the global challenge for wheat nutrition is to increase grain yield while maintaining its protein (Tilman et al., 2002). Wheat yield and its quality depend upon the environment, genotype, and their interactions. Low soil fertility, especially nitrogen (N) deficiency, is one of the major constraints limiting wheat production in India. Thus, increased usage of $\mathrm{N}$ fertilizer and its use efficiency is considered to be a primary means of increasing wheat grain yield and protein content in these areas.

Nitrogen $(\mathrm{N})$ is often the most important and most limiting nutrient for crop yield in many regions of the world. Nitrogenous fertilizer is one of the main inputs for cereals production systems. Nitrogen is the plant nutrient that is often most limiting to efficient and profitable crop production. Inadequate supply of available $\mathrm{N}$ frequently results in plants that have slow growth, low protein levels, poor yield of low quality produce, and inefficient water use. Therefore, application of nitrogen fertilizer at the right rate and time is vital for the enhancement of soil fertility and crop productivity. High levels of $\mathrm{N}$ supply results in a higher protein content, but increased efficiency of utilization is realized when concentration in the kernels increases and grain yield remains stable (Ortiz Monasterio et al., 1997).

Polymer-coated urea, also called plasticcoated urea, or PCU, is a slow releasing fertilizers can permit a more precise rate of nitrogen release Normal Urea. A variety of polymers are used to form semi-permeable coatings on soluble $\mathrm{N}$ sources, usually urea. Release is regulated by polymer chemistry, coating thickness, soil moisture, and soil temperature. Because of high cost, CRN use in agriculture is limited, accounting for less than $1 \%$ of worldwide fertilizer consumption
(Englesjord et al., 1997). The disadvantage of polymer-coated urea products is their relatively high cost compared to Normal Urea. Polymer-coated urea fertilizers use a hydrophobic (water insoluble) coating that temporarily isolates the urea prill from the soil environment. These polymer coatings may be resins or mineral-based products that act as semipermeable membranes or impermeable membranes with tiny pores. Nutrient release through these membranes is controlled by the properties of the coating material, i.e., its permeability characteristics as affected by temperature and moisture. Thus, they are not significantly affected by soil properties such as $\mathrm{pH}$, salinity, soil texture, microbial activity, redox potential or cation exchange capacity. Therefore, it is possible to predict and control the nutrient release rate from these products are more accurately than for Normal Urea (Trenkel, 2010).

\section{Materials and Methods}

The experiment was carried out during Rabi (winter) season of 2016-2017 at the Agricultural Research Farm, Department of soil science and agricultural chemistry, Institute of Agricultural Sciences, Banaras Hindu University, Varanasi, Uttar Pradesh (India). The experimental trial was conducted in field number A/14 of Agricultural Research Farm, B.H.U. This experiment was conducted with 12 treatments and 3 replications of control, $100 \%$ of RDN through normal urea as a single basal dose and as in 3 split, and 100 $\%, 85 \%, 70 \%$ and $55 \%$ RDN through PCU as single basal doses and as in 3 split under randomized block design (RBD) on wheat variety Malviya-510 during Rabi season 20162017. The last treatment $\left(T_{12}\right)$ was comprising with $55 \%$ of RDN through PCU as basal dressing +2 tons FYM ha-1 + PGPR (mixture of Azotobactor chroococcum, Pseudomonas aeruginosa, P. flurescens, P. putida, Bacillus subtilis, Azospirillum brasilense, Trichoderma 
harzianum). The soil of experimental field was low in organic carbon $(0.50 \%)$, medium available $\mathrm{N}\left(178.37 \mathrm{~kg} \mathrm{ha}{ }^{-1}\right)$, medium available $\mathrm{P}\left(18.89 \mathrm{~kg} \mathrm{ha}^{-1}\right)$ and low available $\mathrm{K}\left(244.56 \mathrm{~kg} \mathrm{ha}^{-1}\right)$ with $\mathrm{pH}$ (8.1) and EC $\left(0.208 \mathrm{dSm}^{-1}\right)$.

\section{Growth parameters}

The height of plant was measured from the surface of soil to the tip of plant with the help of a meter scale at 40,80 and harvesting stage after transplanting. Chlorophyll content of the plants was measured by the use of Chlorophyll Meter in SPAD units at 40 and 60 days after transplanting. Chlorophyll content of randomly selected 5 sampled leaves from various wheat plant in net plot area was measured at 40, 60 DAS coinciding with tillering, booting and panicle emergence stage of the crop. Finally, the average value on chlorophyll content were computed and expressed in SPAD unit.

\section{Yield attributes}

Numbers of tillers plant ${ }^{-1}$ were counted at 40 , 80 and harvesting days after transplanting of wheat seedling. The grains yield obtained from each plot were weighed by pan balance in $\mathrm{kg}$ and converted into tons/ha by multiplying with factor 2.5 .The grain yield was subtracted from the biological yield per plot to record the straw yield $\mathrm{kg} / \mathrm{plot}$, which was converted into tons/ha by multiplying with factor 2.5.Biological Yield (kg ha-1) was calculated from all the above ground plants part of each net plot, sun dried and weight in $\mathrm{kg} / \mathrm{plot} \&$ these values were expressed into $\mathrm{kg}$ ha-1.

\section{Plant analysis}

The plant and grain samples collected at harvesting were dried at $60+2^{\circ} \mathrm{C}$ for $48 \mathrm{hrs}$ in a hot air oven and ground to powder. Nitrogen content in plant and grain samples was determined by Modified Kjeldahl Method as per procedure outlined by Gupta (2007). In a digestion tube, $0.5 \mathrm{~g}$ of powdered plant straw was taken and $10 \mathrm{~mL}$ of diacid solution (9:1, $\mathrm{H}_{2} \mathrm{SO}_{4}: \mathrm{HClO}_{4}$ ) was added and kept overnight, $10 \mathrm{~g}$ of sulphate mixture (20 parts $\mathrm{K}_{2} \mathrm{SO}_{4}+1$ part catalyst mixture containing 20 parts $\mathrm{CuSO}_{4}+1$ part selenium powder) was added and heating was done in a digestion chamber till a clear colourless solution was obtained. The suspension was cooled and filtered through Whatman No. 42 filter paper in a 50 $\mathrm{ml}$ volumetric flask and volume was made up with distilled water. $10 \mathrm{~mL}$ of $4 \%$ boric acid solution containing bromocresol green and methyl red indicator was taken in a conical flask, outlet of distillation apparatus was dipped into boric acid solution. $5 \mathrm{~mL}$ of the aliquot was taken and transferred to distillation flask of micro-kjeldahl distillation apparatus and $10 \mathrm{~mL}$ of $40 \% \mathrm{NaOH}$ solution was added. After completion of distillation, boric acid was titrated against $0.02 \mathrm{~N} \mathrm{H}_{2} \mathrm{SO}_{4}$. Blank was also run. One gram dried and powdered (20 mesh) plant sample (20 mesh) was taken in a $50 \mathrm{ml}$ digestion tube and $10 \mathrm{ml}$ di-acid mixture $\left(4: 1 \mathrm{v} / \mathrm{v} \mathrm{HNO}_{3}: \mathrm{HClO}_{4}\right)$ was added to it and was kept overnight. It was then digested on a block digester till a colourless solution was obtained. The volume of acid was reduced till the flask contained only moist residue. The flask was cooled and $25 \mathrm{~mL}$ of distilled water was added to it. The solution was filtered into a $50 \mathrm{~mL}$ volumetric flask and diluted up to mark. $2 \mathrm{ml}$ of digest was taken in a $25 \mathrm{ml}$ volumetric flask and 2 drops of 2, 4 di-nitrophenol indicator was added followed by ammonium solution till appearance of yellow colour. Now $6 \mathrm{~N} \mathrm{HCl}$ was added drop wise till it became colourless. $5 \mathrm{~mL}$ of Vanadate molybdate solution was then added to it and diluted to $25 \mathrm{~mL}$ with distilled water, mixed well and the intensity of yellow colour was read on spectrophotometer by using blue filter at $440 \mathrm{~nm}$ wave length. A blank was also 
run without $\mathrm{P}$ solution simultaneously. Phosphorus content in straw and grain was calculated using standard curve and expressed as total P (\%). Same procedure was followed in determination of $\mathrm{P}$ content in grain except the weight of sample in case of grain was only 0.2g (Jackson 1967). Potassium content in plant and grain was determined by Flame Photometer Method (Jackson, 1973). Digested extract was used directly for flame photometric determination of potassium. K content was calculated using the standard curve and expressed as.

\section{Statistical analysis and interpretation of data}

The data recorded during the course of investigation were subjected to statistical analysis as described by Panse and Sukhatme (1985). The significant effect of treatments was judged with the help of ' $F$ ' (variance ratio) table. The significant differences between of the means were tested against critical differences at 5\% probability level. Analysis of variance for all treatment in Randomized Block Design (RBD) was carried out. For testing the hypothesis the following ANOVA table was used. The significance and non-significant effect of the different treatments was tested with the help of ' $F$ ' variance ratio test. Calculated ' $F$ ' value was compared with table value of ' $\mathrm{F}$ ' at $5 \%$ levels of significance. If calculated value of ' $F$ ' exceeds its table value, the effect was considered to be significant. The significant difference between treatment means was tested using critical difference at $5 \%$ level of significance.

\section{Results and Discussion}

\section{Effect on plant height}

The data pertaining to effect of polymer coated urea (PCU) and normal urea on height of plant hill ${ }^{-1}$ has been presented in table 1 and depicted in figure 1. It is evident from the table 1 that height of plant at 40 DAT varied from 32.82 to $43.07 \mathrm{~cm}$. The maximum height in the range was due to treatment $\mathrm{T}_{5}(70 \%$ of RDN through PCU 3 Split) followed by 42.57 $\mathrm{cm}$ due to $\mathrm{T}_{4}$ (85\% of RDN through PCU 3 Split). Significant differences were found between the treatments of PCU application in the plot. The treatment of normal urea with three split $\left(\mathrm{T}_{3}\right)$ and single basal dose $\left(\mathrm{T}_{7}\right)$ gave plant height hill $^{-1} 39.33$ and $38.67 \mathrm{~cm}$ respectively. Moreover, control plot with RDF showed a lowest plant height of $32.82 \mathrm{~cm}$ at 40 DAS. However, at 80 DAS the treatment $\mathrm{T}_{2}$ and at harvesting stage the treatment $\mathrm{T}_{3}$ was found higher value over other treatment. Chen Yi Wang et al., (2002) have also reported similar trends of plant growth of wheat receiving common urea or polymer-coated urea under micro plot field experiments.

\section{Effect on chlorophyll content (SPAD value)}

Data pertaining to the chlorophyll content (SPAD value) in leaf as influenced by normal urea, PCU, FYM and PCU+PGPR application has been given in table 1 . There was a significant increase in chlorophyll content at 40 DAT with the application of normal urea, PCU, FYM and PCU+PGPR. The maximum chlorophyll content $\left(39.35 \mu \mathrm{g} \mathrm{mL} \mathrm{mL}^{-1}\right)$ in leaf was found in treatment $\mathrm{T}_{7}(100 \%$ of RDN through Urea Single Basal) followed by $\mathrm{T}_{10}$ (70\% of RDN through PCU Single Basal) $39.03 \mu \mathrm{g} \mathrm{mL}^{-1}$. The minimum chlorophyll content $\left(25.83 \mu \mathrm{g} \mathrm{mL} \mathrm{mL}^{-1}\right)$ was found in treatment $\mathrm{T}_{1}$ (control). The application of FYM and PGPR in addition to $55 \%$ RDN through PCU Single Basal $\left(\mathrm{T}_{12}\right)$ had shown chlorophyll content $40.96 \%$ more over the Control. While with decreasing the percentage of PCU with three split application found at par in $\mathrm{T}_{4}(85 \%), \mathrm{T}_{5}(70 \%)$ and $\mathrm{T}_{6}(55 \%)$ and with single basal dose was found at par value of chlorophyll due in $\mathrm{T}_{9}(85 \%), \mathrm{T}_{10}(70 \%)$ and 
$\mathrm{T}_{11}$ (55\%). GuJia Lin et al., (2009) have reported that nitrogen release characteristic of macromolecule polymer coated urea (PCU) by laboratory method of water dissolve and the effects of applied PCU on tall fescue turf as basal application in spring was studied.

\section{Effect on number of tillers per hill}

A critical perusal of the data presented in Table 2 revealed that a significant increase was found in number of tillers at 40 DAS with the three split application of PCU than single basal dose of PCU and normal urea. While a significant increase in number of tillers also noted with single basal application of PCU with FYM, PGPR. Split application of PCU resulted significant increase in number of tillers at 40 DAS due to minimization of loss and higher nutrient efficiency as compared to single basal dose of PCU and other nutrient sources. The maximum number of tillers (3.80) was noted in $\mathrm{T}_{2}(100 \%$ of $\mathrm{RDN}$ through urea Single Basal) and minimum number of tillers (2.40) in $\mathrm{T}_{1}$ (control) at 40 DAS. The application of PCU in treatment $\mathrm{T}_{8}$ (100\% of RDN through PCU Single Basal) increased number of tillers by $45.83 \%$ over the control, while $\mathrm{T}_{\mathbf{1 2}}$ (55\% of RDN through PCU Single Basal + FYM + PGPR) increased $8.33 \%, \mathrm{~T}_{4}(85 \%$ of RDN through PCU 3 Split) increased $44.58 \%, \mathrm{~T}_{5}(70 \%$ of RDN through PCU 3 Split) increased $50 \%$ and $\mathrm{T}_{6}$ (55\% of RDN through PCU 3 Split) increased $30.41 \%$. Almost similar and increasing trend was noticed with the number of tillers recorded at 80 DAS and a similar but decreasing trend at harvesting as compared to 40 DAS.

\section{Effect on spike length}

Data pertaining to the spike length presented in table 2 showed that at 80 DAT maximum spike length of $7.37 \mathrm{~cm}$ was recording with split application of PCU in $\mathrm{T}_{2}(100 \%$ of RDN through urea 3 Split) and minimum spike length of $5.13 \mathrm{~cm}$ in $\mathrm{T}_{1}$ (control). The maximum spike length recorded in $\mathrm{T}_{8}(100 \%$ of RDN through PCU Single Basal). We found that the spike length of treatment $\mathrm{T} 8$ is $39.76 \%, 35.08 \%, 26.70 \%$ increase over control $\left(\mathrm{T}_{1}\right), \mathrm{T} 12$ (55 \% of RDN through PCU Single Basal + FYM + PGPR), $\mathrm{T}_{4}(85 \%$ of RDN through PCU 3 Split) respectively. While $43.66 \%$ increase over control in $\mathrm{T}_{2}$ (100\% of RDN through Urea 3 Split) and in $\mathrm{T}_{7}$ (100\% of RDN through Urea Single Basal) an increase of $32.55 \%$. Moreover, $\mathrm{T}_{5}(70 \%$ of RDN through PCU 3 Split), $\mathrm{T}_{6}(55 \%$ of RDN through PCU 3 Split), $\mathrm{T}_{9}$ (85\% of RDN through PCU Single Basal), $\mathrm{T}_{10}(70 \%$ of RDN through PCU Single Basal) and $\mathrm{T}_{4}(85$ $\%$ of RDN through PCU 3 split) found at par. A similar trend was recorded at harvesting for spike length.

Effect of different levels of recommended dose of nitrogen (RDN) through PCU and $\mathrm{NU}$ on biological, grain and straw yield of wheat

A critical perusal of the data presented in table 3 revealed that the grain yield of wheat was ranging from $27.33 \mathrm{qha}^{-1}$ to $55.10 \mathrm{qha}^{-1}$ and it has increased significantly with the split application of PCU at different levels. The maximum grain yield $\left(55.10 \mathrm{qha}^{-1}\right)$ was recorded in the treatment $\mathrm{T}_{3}(100 \%$ of $\mathrm{RDN}$ through PCU 3 Split). Among the split application treatment $T_{3}$ record the maximum yield which is significant $101.31 \%$ and 51.51 $\%$ increase over control $\left(\mathrm{T}_{1}\right)$ and $\mathrm{T}_{5}(70 \%$ of RDN through PCU 3 Split). Compare to other split dose treatment $T_{3}$ are non-significant increase. But compare to the basal dose application the maximum grain yield in $\mathrm{T}_{12}$ (55\% of RDN through PCU Single Basal + FYM + PGPR) is $53.40 \mathrm{q} \mathrm{ha}^{-1}$ which has been only $4.74 \%$ less than $\mathrm{T}_{3}$. The straw yield of wheat was ranging from $50.53 \mathrm{q} \mathrm{ha}^{-1}$ to 89.67 $\mathrm{q} \mathrm{ha}^{-1}$. 
Table.1 Effect of different levels of recommended dose of nitrogen (RDN) through PCU on plant height and chlorophyll content (SPAD value) in leaves of wheat at different days of interval

\begin{tabular}{|c|c|c|c|c|c|c|}
\hline \multicolumn{2}{|r|}{ Treatment } & \multicolumn{3}{|c|}{ Average Plant height hill ${ }^{-1}(\mathrm{~cm})$} & \multicolumn{2}{|c|}{$\begin{array}{l}\text { Chlorophyll in } \\
\text { leaves }\left(\mu \mathrm{g} \mathrm{ml} \mathbf{~ m}^{-1}\right)\end{array}$} \\
\hline & & 40 DAS & 80 DAS & $\begin{array}{c}\text { At } \\
\text { harvesting }\end{array}$ & 40 DAS & 60 DAS \\
\hline $\mathbf{T}_{1}$ & Control & 32.82 & 76.09 & 81.30 & 25.83 & 24.61 \\
\hline $\mathbf{T}_{2}$ & $100 \%$ of RDN through Urea 3 Split & 39.33 & 96.77 & 94.20 & 33.15 & 31.99 \\
\hline$\overline{T_{3}}$ & $100 \%$ of RDN through PCU 3 Split & 41.47 & 94.73 & 97.70 & 38.90 & 36.69 \\
\hline $\mathbf{T}_{4}$ & $85 \%$ of RDN through PCU 3 Split & 42.57 & 96.20 & 96.20 & 37.36 & 36.77 \\
\hline $\mathbf{T}_{5}$ & $70 \%$ of RDN through PCU 3 Split & 43.07 & 91.70 & 94.57 & 38.40 & 36.31 \\
\hline$T_{6}$ & $55 \%$ of RDN through PCU 3 Split & 40.20 & 91.43 & 88.30 & 35.10 & 33.30 \\
\hline $\mathbf{T}_{7}$ & $100 \%$ of RDN through Urea Single Basal & 38.67 & 84.93 & 89.13 & 39.35 & 38.31 \\
\hline $\mathbf{T}_{8}$ & $100 \%$ of RDN through PCU Single Basal & 41.07 & 95.47 & 91.50 & 38.88 & 37.93 \\
\hline$T_{9}$ & $85 \%$ of RDN through PCU Single Basal & 41.17 & 94.83 & 93.53 & 40.35 & 37.60 \\
\hline $\mathbf{T}_{10}$ & $70 \%$ of RDN through PCU Single Basal & 42.33 & 95.00 & 98.57 & 39.03 & 36.00 \\
\hline $\mathbf{T}_{11}$ & $55 \%$ of RDN through PCU Single Basal & 40.47 & 95.53 & 97.13 & 36.57 & 35.08 \\
\hline $\mathbf{T}_{12}$ & $\begin{array}{l}55 \% \text { of RDN through PCU Single Basal } \\
+40 \mathrm{Kg} \mathrm{P}+\text { FYM @ } 2 \mathrm{tha}^{-1}+\text { PGPR }\end{array}$ & 36.70 & 92.43 & 96.53 & 36.41 & 34.17 \\
\hline & SEm \pm & 0.954 & 1.421 & 1.089 & 1.900 & 1.931 \\
\hline & CD at $5 \%$ & 1.974 & 2.941 & 2.253 & 3.934 & 3.998 \\
\hline
\end{tabular}

Table.2 Effect of different levels of RDN through PCU on No. of tillers and spike length of wheat at different days of interval

\begin{tabular}{|c|c|c|c|c|c|c|}
\hline \multicolumn{2}{|r|}{ Treatment } & \multicolumn{3}{|c|}{ No. of tillers hill ${ }^{-1}$} & \multicolumn{2}{|c|}{ spike length (cm) } \\
\hline & & $\begin{array}{c}40 \\
\text { DAS }\end{array}$ & $\begin{array}{c}80 \\
\text { DAS }\end{array}$ & $\begin{array}{c}\text { At } \\
\text { harvesting }\end{array}$ & $\begin{array}{c}80 \\
\text { DAS }\end{array}$ & $\begin{array}{c}\text { At } \\
\text { harvesting }\end{array}$ \\
\hline$T_{1}$ & Control & 2.40 & 4.47 & 4.30 & 5.13 & 6.27 \\
\hline $\mathbf{T}_{2}$ & $100 \%$ of RDN through Urea 3 Split & 3.80 & 9.17 & 8.47 & 7.37 & 7.93 \\
\hline $\mathrm{T}_{3}$ & $100 \%$ of RDN through PCU 3 Split & 3.67 & 6.83 & 6.53 & 7.10 & 7.60 \\
\hline$T_{4}$ & $85 \%$ of RDN through PCU 3 Split & 3.47 & 7.27 & 7.23 & 6.50 & 7.50 \\
\hline$T_{5}$ & $70 \%$ of RDN through PCU 3 Split & 3.60 & 4.97 & 5.03 & 6.30 & 7.10 \\
\hline$T_{6}$ & $55 \%$ of RDN through PCU 3 Split & 3.13 & 6.63 & 6.67 & 6.03 & 7.20 \\
\hline $\mathbf{T}_{7}$ & $100 \%$ of RDN through Urea Single Basal & 3.27 & 8.07 & 7.47 & 6.80 & 7.67 \\
\hline $\mathrm{T}_{8}$ & $100 \%$ of RDN through PCU Single Basal & 3.50 & 6.87 & 6.40 & 7.17 & 7.83 \\
\hline$T_{9}$ & $85 \%$ of RDN through PCU Single Basal & 3.33 & 6.50 & 6.20 & 6.30 & 7.67 \\
\hline $\mathbf{T}_{10}$ & $70 \%$ of RDN through PCU Single Basal & 3.40 & 7.57 & 7.30 & 6.50 & 7.77 \\
\hline $\mathbf{T}_{11}$ & $55 \%$ of RDN through PCU Single Basal & 3.20 & 7.93 & 7.50 & 6.67 & 7.73 \\
\hline $\mathbf{T}_{12}$ & $\begin{array}{l}55 \% \text { of RDN through PCU Single Basal }+40 \\
\text { Kg P + FYM @ } 2 \mathrm{tha}^{-1}+\text { PGPR }\end{array}$ & 2.60 & 7.83 & 7.63 & 6.93 & 7.93 \\
\hline & SEm \pm & 0.193 & 0.334 & 0.306 & 0.217 & 0.203 \\
\hline & CD at $5 \%$ & 0.400 & 0.690 & 0.633 & 0.450 & 0.420 \\
\hline
\end{tabular}


Table.3 Effect of different levels of RDN through PCU on yield of wheat at harvesting

\begin{tabular}{|c|c|c|c|c|}
\hline \multirow{2}{*}{\multicolumn{2}{|c|}{ Treatment }} & \multicolumn{3}{|c|}{ Yield $\left(\mathbf{q ~ h a} \mathbf{a}^{-1}\right)$} \\
\hline & & Biological & Grain & Straw \\
\hline $\mathbf{T}_{1}$ & Control & 77.90 & 27.37 & 50.53 \\
\hline$\overline{T_{2}}$ & $100 \%$ of RDN through Urea 3 Split & 110.63 & 47.30 & 63.33 \\
\hline $\mathbf{T}_{\mathbf{3}}$ & $100 \%$ of RDN through PCU 3 Split & 136.00 & 55.10 & 80.90 \\
\hline $\mathbf{T}_{4}$ & $85 \%$ of RDN through PCU 3 Split & 119.87 & 48.47 & 71.40 \\
\hline $\mathbf{T}_{\mathbf{5}}$ & $70 \%$ of RDN through PCU 3 Split & 128.57 & 41.00 & 87.57 \\
\hline$T_{6}$ & $55 \%$ of RDN through PCU 3 Split & 121.47 & 46.07 & 75.40 \\
\hline $\mathbf{T}_{7}$ & $100 \%$ of RDN through Urea Single Basal & 106.80 & 39.37 & 67.43 \\
\hline $\mathbf{T}_{8}$ & $100 \%$ of RDN through PCU Single Basal & 130.67 & 53.03 & 77.63 \\
\hline $\mathbf{T}_{9}$ & $85 \%$ of RDN through PCU Single Basal & 134.77 & 46.00 & 88.77 \\
\hline $\mathbf{T}_{10}$ & $70 \%$ of RDN through PCU Single Basal & 130.83 & 41.93 & 88.90 \\
\hline $\mathbf{T}_{11}$ & $55 \%$ of RDN through PCU Single Basal & 124.93 & 46.87 & 78.07 \\
\hline $\mathrm{T}_{12}$ & $\begin{array}{l}55 \% \text { of RDN through PCU Single Basal } \\
+40 \mathrm{Kg} \mathrm{P}+\mathrm{FYM} @ 2 \mathrm{t} \mathrm{ha}^{-1}+\mathrm{PGPR}\end{array}$ & 143.47 & 53.80 & 89.67 \\
\hline & SEm \pm & 0.141 & 0.043 & 0.124 \\
\hline & CD at $5 \%$ & 0.292 & 0.090 & 0.257 \\
\hline
\end{tabular}

Table.4 Content of N, P and K levels of recommended dose of nitrogen (RDN) through PCU in grain and straw of wheat as affected by different $\mathrm{N}$ levels and methods of application through

PCU and NU

\begin{tabular}{|c|c|c|c|c|c|c|c|}
\hline \multirow{2}{*}{\multicolumn{2}{|c|}{ Treatment }} & \multicolumn{3}{|c|}{ Content in grain } & \multicolumn{3}{|c|}{ Content in straw } \\
\hline & & $\mathbf{N}(\%)$ & $\mathbf{P}(\%)$ & $\mathbf{K}(\%)$ & $\mathbf{N}(\%)$ & $\mathbf{P}(\%)$ & $\mathbf{K}(\%)$ \\
\hline$T_{1}$ & Control & 1.109 & 0.273 & 0.41 & 0.514 & 0.059 & 0.682 \\
\hline$T_{2}$ & $100 \%$ of RDN through Urea 3 Split & 1.544 & 0.320 & 0.52 & 0.529 & 0.062 & 1.137 \\
\hline$T_{3}$ & $100 \%$ of RDN through PCU 3 Split & 1.580 & 0.367 & 0.59 & 0.575 & 0.071 & 1.273 \\
\hline$\overline{T_{4}}$ & $85 \%$ of RDN through PCU 3 Split & 1.563 & 0.350 & 0.57 & 0.562 & 0.067 & 1.247 \\
\hline$T_{5}$ & $70 \%$ of RDN through PCU 3 Split & 1.534 & 0.343 & 0.56 & 0.552 & 0.066 & 1.220 \\
\hline$T_{6}$ & $55 \%$ of RDN through PCU 3 Split & 1.527 & 0.333 & 0.54 & 0.532 & 0.065 & 1.203 \\
\hline $\mathbf{T}_{7}$ & $\begin{array}{l}100 \% \text { of RDN through Urea Single } \\
\text { Basal }\end{array}$ & 1.516 & 0.310 & 0.50 & 0.518 & 0.062 & 1.103 \\
\hline $\mathbf{T}_{8}$ & $\begin{array}{l}100 \% \text { of RDN through PCU Single } \\
\text { Basal }\end{array}$ & 1.563 & 0.360 & 0.58 & 0.562 & 0.069 & 1.247 \\
\hline$T_{9}$ & $85 \%$ of RDN through PCU Single Basal & 1.556 & 0.327 & 0.56 & 0.545 & 0.066 & 1.223 \\
\hline$\overline{T_{10}}$ & $70 \%$ of RDN through PCU Single Basal & 1.546 & 0.297 & 0.54 & 0.536 & 0.064 & 1.187 \\
\hline$T_{11}$ & $55 \%$ of RDN through PCU Single Basal & 1.534 & 0.293 & 0.52 & 0.529 & 0.063 & 1.157 \\
\hline $\mathrm{T}_{12}$ & $\begin{array}{l}55 \% \text { of RDN through PCU Single Basal } \\
+40 \mathrm{Kg} \text { P + FYM @ } 2 \mathrm{t} \mathrm{h}^{-1}+\text { PGPR }\end{array}$ & 1.549 & 0.347 & 0.56 & 0.525 & 0.067 & 1.240 \\
\hline & SEm \pm & 0.029 & 0.009 & 0.014 & 0.011 & 0.001 & 0.137 \\
\hline & CD at 5\% & 0.060 & 0.018 & 0.028 & 0.023 & 0.003 & 0.284 \\
\hline
\end{tabular}


The maximum straw yield $\left(89.67 \mathrm{q} \mathrm{ha}^{-1}\right)$ was recorded in the treatment $\mathrm{T}_{12}(55 \%$ of $\mathrm{RDN}$ through PCU Single Basal + FYM + PGPR) and T12 was found significantly $77.45 \%$ higher over control. Among the split dose $\mathrm{T}_{5}$ (70 \% of RDN through PCU 3 Split) record the maximum straw yield $\left(87.57 \mathrm{q} \mathrm{ha}^{-1}\right)$ was found significant $73.30 \%$ higher over control treatment $\left(\mathrm{T}_{1}\right)$. The total biological yield tent to slightly decrease with decrease the fertilizer level and found statistical significance over treatment control $\mathrm{T}_{1}$ presented in table 3. It range from $77.46 \mathrm{q}$ $\mathrm{ha}^{-1}$ and $143.47 \mathrm{q} \mathrm{ha}^{-1}$ from treatment $\left(\mathrm{T}_{1}\right)$ to treatment $\left(\mathrm{T}_{12}\right)$ respectively. The treatment $\left(\mathrm{T}_{12}\right)$ was found significantly $81.17 \%$ higher than the treatment control $\left(\mathrm{T}_{1}\right)$.However, among the all the maximum biological yield and straw yield was found in the treatment $\left(\mathrm{T}_{12}\right)$ and maximum yield value occurred in the treatment $\left(\mathrm{T}_{1}\right)$. These treatments are statistically significant over treatment control $\left(\mathrm{T}_{1}\right)$. Singh et al., (1995) reported that grain yield of lowland wheat from a single application of polymer coated urea (PCU) was equivalent to or better than 3-4 time split application of urea. Fertilizer recovery with PCU was $70-75 \%$ compared to $50 \%$ with prilled urea.

Effect of different levels of recommended dose of nitrogen (RDN) through PCU and NU on content of nutrients in grain and straw

\section{Nitrogen, phosphorus and potassium content in grain and straw}

A critical observation of the data given in Table 4 marks it clear that effect of application of PCU, UREA, FYM and PGPR on nitrogen content in wheat grain varied significantly. The higher $\mathrm{N}$ content in grain followed in treatment $\mathrm{T}_{3}(1.58 \%)$ and lower $\mathrm{N}$ content in grain followed in treatment $\mathrm{T}_{1}$ $(1.109 \%)$. The maximum content of nitrogen in grain was found in $\mathrm{T}_{3}(100 \%$ of $\mathrm{RDN}$ through PCU 3 Split), which was $4.22 \%$ higher over $\mathrm{T}_{7}(100 \%$ of RDN through Urea Single Basal), $2.33 \%$ higher over $\mathrm{T}_{2}(100 \%$ of RDN through Urea 3 Split), $1.08 \%$ higher over $\mathrm{T}_{4}$ (85\% of RDN through PCU 3 Split), $2.0 \%$ higher over T12 (55\% of RDN through PCU Single Basal + FYM + PGPR) and 1.02 $\%$ higher over $\mathrm{T}_{8}(100 \%$ of RDN through PCU Single Basal). The higher N content in straw followed in treatment $\mathrm{T}_{3}(0.575 \%)$ and lower $\mathrm{N}$ content in straw followed in treatment $\mathrm{T}_{1}(0.514 \%)$. Spilt application of PCU showed significantly higher nitrogen content in straw $(0.575 \%)$ over control $\left(\mathrm{T}_{1}\right)$. The maximum content of nitrogen in straw was found in $\mathrm{T}_{3}(100 \%$ of RDN through PCU 3 Split), which was $11.00 \%$ higher over $\mathrm{T}_{7}$ (100\% of RDN through Urea Single Basal), $8.69 \%$ higher over $\mathrm{T}_{2}(100 \%$ of RDN through Urea 3 Split), $2.31 \%$ higher over $\mathrm{T}_{4}(85 \%$ of RDN through PCU 3 Split), $9.52 \%$ higher over T12 (55\% of RDN through PCU Single Basal + FYM + PGPR) and $2.31 \%$ higher over $\mathrm{T}_{8}(100 \%$ of RDN through PCU Single Basal). The maximum $\mathrm{P}$ content in grain followed in treatment $\mathrm{T}_{3}(0.36 \%)$ and minimum $\mathrm{P}$ content in treatment $\mathrm{T}_{1}(0.27 \%)$. The treatment $\mathrm{T}_{3}(100 \%$ of $\mathrm{RDN}$ through PCU 3 Split) $34.43 \%$ was found increase the phosphorus content in wheat grain over the treatment $\mathrm{T}_{1}$ (control) while $\mathrm{T}_{8}(100 \%$ of RDN through PCU Single Basal) showed $31.86 \%$ over the treatment $\mathrm{T}_{1}$ (control). The inoculation of PGPR $\left(\mathrm{T}_{12}\right)$ significantly increases the phosphorus content in wheat grain $27.10 \%$ over $\mathrm{T}_{1}$ but less than that of $\mathrm{T}_{3}$. The higher $\mathrm{P}$ content in straw followed in treatment $\mathrm{T}_{3}(0.071 \%)$ and lower $\mathrm{P}$ content in straw followed in treatment $\mathrm{T}_{1}(0.059 \%)$. The treatment $\mathrm{T}_{3}(100 \%$ of RDN through PCU 3 Split) $20.33 \%$ was found increase the phosphorus content in straw over the treatment $\mathrm{T}_{1}$ (control). "The inoculation of PGPR+FYM+SSP $\quad\left(\mathrm{T}_{12}\right) \quad$ significantly increases the phosphorus content in wheat 
straw $13.55 \%$ over control $\left(\mathrm{T}_{1}\right)$. The higher $\mathrm{K}$ content in grain followed in treatment $\mathrm{T}_{3}(0.59$ $\%$ ) and lower $\mathrm{K}$ content in grain followed in treatment $\mathrm{T}_{1}(0.041 \%)$. The treatment $\mathrm{T}_{3}$ (100\% of RDN through PCU 3 Split) was found $43.90 \%$ increase the potassium content in grain over the treatment $\mathrm{T}_{1}$ (control), 13.46 $\%$ and $18.00 \%$ higher over $\mathrm{T}_{2}(100 \%$ of RDN through Urea 3 Split) and $\mathrm{T}_{7}(100 \%$ of RDN through Urea Single Basal) respectively. The higher potassium content in straw $(2.73 \%)$ was obtained with the split application of 100 $\%$ PCU in $\mathrm{T}_{3}$, The lowest potassium content in straw $(0.68 \%)$ was recorded in the treatment $\mathrm{T}_{1}$ (control). The treatment $\mathrm{T}_{3}(100$ $\%$ of RDN through PCU 3 Split) and $\mathrm{T}_{8}(100$ $\%$ of RDN through PCU Single Basal) 86.65 $\%$ and $82.84 \%$ was found increase the potassium content in straw over the treatment $\mathrm{T}_{1}$ (control). Among the all the treatment the $\mathrm{N}, \mathrm{P}$ and $\mathrm{K}$ content in grain and straw the maximum content in treatment $\left(\mathrm{T}_{3}\right)$ which is significant over the control treatment $\left(\mathrm{T}_{1}\right)$.

In the present investigation, the treatment involving three split application of $70 \%$ of RDN through polymer coated urea showed a significant increase in plant height at 40 DAS. The treatment $\mathrm{T}_{2}$ (100\% of RDN through urea 3 split) showed a significant increase in plant height at 80 DAS. But at harvesting stage maximum height of plant was due to treatment $\mathrm{T}_{3}$ (100\% of RDN through PCU 3 split). The increases in number of tillers at 40 , 80 DAS and harvesting stage was significantly higher over control due to treatment $\mathrm{T}_{2} \quad(100 \%$ Urea three split application). The treatment $\mathrm{T}_{10}(70 \%$ of RDN through Urea single basal) and treatment $\mathrm{T}_{7}$ (100\% of RDN through PCU single basal) showed significantly higher SPAD value over control at 40 DAS and 80 DAS respectively. Application of PCU and urea found significantly effective to enhance grain and straw yield of wheat. The maximum grain yield $\left(\mathrm{q} \mathrm{ha}{ }^{-1}\right)$ was obtained when $100 \%$ of nitrogen was applied through PCU in split doses $\left(T_{3}\right)$ which registered significant over control and other treatment. Only those treatments which received split application of PCU showed significantly higher $\mathrm{N}$ content in the wheat grains than the control. $\mathrm{N}$ content was varying in grain from 27.72 to $39.5 \mathrm{mg}$ $\mathrm{kg}^{-1}$ and in straw from 25.7 to $28.75 \mathrm{mg} \mathrm{kg}^{-1}$ significantly higher over control and treatments of receiving split and single basal doses of urea. The result of the present investigation conferred that a significant increase in grain and straw yield of wheat along with other growth and yield attribute, $\mathrm{N}, \mathrm{P}$ and $\mathrm{K}$ content and uptake by wheat crop can be obtained with application of PCU over urea. Thus, $\mathrm{N}$ nutrition via PCU in split application of the wheat crop holds immense importance for obtaining better growth and productivity. Increasing $\mathrm{N}$ concentration in wheat grains is important to address the health problem of nutrient deficient food grain and malnutrition besides better crop production. Split application of PCU in the soil at sowing and at maximum tillering and milking stage was most effective for enriching the grains with $\mathrm{N}$ and to obtain the better bioavailability of the polymer coated N. However, for maximum grain yield, 3 split application of $100 \%$ PCU of treatment $\mathrm{T}_{3}$ hold promise. Therefore, application of treatment $100 \%$ of RDN through PCU 3 split may be recommended to the farmer, after its further testing on their own field, for better growth and yield of wheat.

\section{References}

Bouwman, A. F., Boumans, L. J. M. and Batjes, N. H., (2002). Modeling global annual $\mathrm{N}_{2} \mathrm{O}$ and $\mathrm{NO}$ emissions from fertilized fields. Global Biogeochemical Cycles, 16(4).

Bouyoucos, G. J. (1962). Hydrometer method improved for making particle size 
analyses of soils. Agronomy journal, 54(5), 464-465.

Chopra, S. L., \& Kanwar, J. S. (1982). Analytical agricultural chemistry Kalyani Publishers. Ludhiana, India.

Engelsjord, M. E. and Singh, B. R., (1997). Effects of slow-release fertilizers on growth and on uptake and leaching of nutrients in Kentucky bluegrass turfs established on sand-based root zones. Canadian journal of plant science, 77(3), 433-444.

GuJiaLin, Wang ChongWang, Li YuQuan, Yi WenPing, Li YaXing and Yang YiBin, (2010). Nitrogen release characteristics of coated urea and its effect on spring maize with touching application. Plant Nutrition and Fertilizer Science, 16(6), 1486-1491

Ortiz-Monasterio, R., Sayre, K. D., Rajaram, S. and McMahon, M., (1997). Genetic progress in wheat yield and nitrogen use efficiency under four nitrogen rates. Crop Science, 37(3), 898-904.

Shewry, P. R., (2009). Wheat. Journal of experimental botany, 60(6), 1537-1553.
Subbiah, B.V. and Asija, G.L. (1956) A rapid procedure for the determination of available nitrogen in soil. Current Science 25, 259-260.

Tilman, D., Cassman, K. G., Matson, P. A., Naylor, R. and Polasky, S., (2002). Agricultural sustainability and intensive production practices. Nature, 418 (6898), 671-677.

Trenkel, M. E., (2010). Slow-and controlledrelease and stabilized fertilizers: An option for enhancing nutrient use efficiency in agriculture. IFA, International fertilizer industry association.

Vitousek, P. M., Aber, J. D., Howarth, R. W., Likens, G. E., Matson, P. A., Schindler, D. W. and Tilman, D. G., (1997). Human alteration of the global nitrogen cycle: sources and consequences. Ecological applications, 7(3), 737-750.

Walkley, A. and Black, C.A. (1934). An examination of the Degtjareff method for determining soil organic matter, and a proposed modification of the chromic acid titration method. Soil Science37, 29-38.

\section{How to cite this article:}

Devendra Kumar Inwati, Janardan Yadav, Jay Shankar Yadav, Giriraj and Astha Pandey. 2018. Effect of Different Levels, Sources and Methods of Application of Nitrogen on Growth and Yield of Wheat (Triticum aestivum L.). Int.J.Curr.Microbiol.App.Sci. 7(02): 2398-2407. doi: https://doi.org/10.20546/ijcmas.2018.702.292 